This is an accepted manuscript of an article published by Springer in Population and Environment on 13 February 2015. The final publication is available at Springer via http://dx.doi.org/10.1007/s11111-015-0234-7

Please cite as:

Marois, Guillaume, and Alain Bélanger. 2015. "Analyzing the impact of urban planning on population distribution in the Montreal metropolitan area using a small-area microsimulation projection model." Population and Environment 37 (2):131-156. doi: $10.1007 /$ s11111-015-0234-7. 


\section{Analysing the Impact of Urban Planning on Population Distribution in the Montreal Metropolitan Area using a Small-Area Microsimulation Projection Model}

\section{Abstract}

The objective of this paper is to project the population of the Montreal Metropolitan Community's municipalities over the 2006-2031 period and assess the effects of changes to urban planning on the expected spatial distribution of the population. For this purpose, we develop a microsimulation model that performs small-area population projections at a municipal level. This model, called Local Demographic Simulations (LDS), takes into account local contextual variables such as the expected number of new housing units to be built. We then compare the results from three scenarios with different constraints on the planned residential development of municipalities. We show that although urban sprawl cannot be avoided, increasing the development potential of the central area can slow it. Results also suggest that the age structure of the central area is not significantly affected by different mobility patterns.

Key Words: Projection, Population, Small area, Microsimulation, Contextual factors, Montreal

\section{Résumé}

L'objectif de cet article est de projeter la population des municipalités de la Communauté Métropolitaine de Montréal pour la période 2006-2031 et de mesurer l'effet de changements dans les plans de développement urbain sur la distribution future de la population. À cet effet, nous avons développé un modèle de microsimulation qui effectue des projections locales à l'échelle des municipalités. Ce modèle, nommé Local 
Demographic Simulations (LDS), prend en considération des variables contextuelles locales telles que le nombre de nouveaux logements construits. Nous comparons les résultats de trois scénarios ayant différentes contraintes relatives au développement résidentiel planifié des municipalités. Nous montrons que malgré le fait que l'étalement urbain puisse difficilement être contré, il pourrait être ralenti en augmentant le potentiel de développement des zones centrales. Les résultats suggèrent également que la structure par âge de la ville centre n'est pas affectée par les différentes dynamiques de mobilité.

\section{Introduction}

Small area population projections are very useful for planning purposes such as ensuring public services under local government responsibility (aqueducts, parks, waste collection, etc.) (Foss, 2002; Isserman, 1984; Swanson \& Pol, 2008). The planning of local services and needs including childcare and services for the elderly, also require information on the future composition of the population on a local level (Harding, Vidyattama, \& Tanton, 2011). However, most demographic projections are conducted on national or regional levels and these are mainly used for planning public policies on a broader scale.

Small area population projections can also be used as a prospective approach to measuring the impact of a change in public policy on the population's spatial distribution (Ballas, Clarke, \& Wiemers, 2005; Wilson, 2011). For example, urban sprawl, which is a challenge for many metropolitan areas, affecting many policy concerns, can be assessed by and analysis of the expected population distribution produced by small area population 
projections (Umbelino, 2012; Waddell, 2000, 2002). Some argue that urban sprawl leads to a redundancy of infrastructure because: 1) new infrastructure must be built in new developments, while existing infrastructure is underutilized in older neighborhoods and because infrastructure in low density sectors are less efficient (Barcelo \& Trépanier, 1999; Burchell et al., 2002; Nechyba \& Walsh, 2004). Additionally, since many metropolitan areas are located on fertile land, urban sprawl transforms its agricultural vocation, increasing food dependency (Montminy, 2010; Roberts, 2001). Another problem related to urban sprawl is the increasing use of cars, leading to more air pollution and more traffic congestion (Nechyba \& Walsh, 2004). While urban sprawl concerns local governments, which manage the zoning of their territory and provide some services, as well as regional and national governments, which need to ensure some consistency in the metropolitan regional development and in the development of major roads and transit, many specialists have called on authorities to regulate urban sprawl (Filion, 1993; Neuman, 2005). However, for many reasons, urban sprawl is still ongoing and urban plans that try to limit the phenomenon are often bypassed (Brueckner, 2000; Huard, Deshaies, \& Garand, 2010).

In a previous paper, we developed a small area population projection model called LDS (Local Demographic Simulations) for the Montreal Metropolitan Community (MMC) ${ }^{1}$. LDS is a time-based microsimulation model that takes into account contextual variables including residential location parameters for both external and internal migrants (Add

\footnotetext{
${ }^{1}$ The MMC is the administrative entity of the metropolitan area of Montreal, which is located in the province of Québec in Canada. It counts about 3.6 million inhabitants in 2006 distributed in 82 municipalities. For the purpose of the projection, three municipalities have however been aggregated with an adjacent municipality because of their small population size.
} 
reference later). Among the contextual variables, the number of new housing units forecast for construction in the urban plan is a key driver of mobility and of population growth on the local level (Dittgen, 2008; Kanaroglou et al., 2009; Bergouignan, 2012).

The objective of this paper is to project the population of municipalities of the Montreal Metropolitan Community for the 2006-2031 time horizon and assess the plausible effect of a change in urban planning on its spatial distribution. To reach this objective, results from three scenarios using different numbers of expected new housings units were compared. Furthermore, as explained later, the previous version of LDS (LDS 1.0) was adequate for forecasting purposes but needed some improvement in the modeling of internal mobility for a prospective approach to urban planning. This paper will therefore also present the main changes made to this second version of LDS (LDS 2.0).

\section{Challenges of small area population projections}

Traditional methods of demographic projections such as the cohort-component or the multi-state approaches are not appropriate for small area population projection because they are unable to account for all spatial interactions (Harding et al., 2011). Small areas often have small population sizes, especially when the population is disaggregated by age and sex. This means it is harder to accurately estimate the components of change for these areas (Ballas, Rossiter, Thomas, Clarke, \& Dorling,

2005; Cameron \& Poot, 2011; Keyfitz, 1972; Lutz, 2009). Additionally, the geographical aspect is much more significant on a local level, where the available space for new housings units is often limited (more so than on the regional level) since many contextual variables can strongly affect population growth (Ballas, Rossiter, et al., 2005). 
Internal mobility is very volatile and it is a major component of population change on a local level. It can be affected by variables such as urban planning, physical characteristics, and distance from the downtown area as well as the socio-demographic composition of the area (Cameron \& Poot, 2011; Chi, Zhou, \& Voss, 2011; Murdock, Hamm, Voss, Fannin, \& Pecotte, 1991). Furthermore, the implementation of urban planning in local demographic projections is important to avoiding a potential selffulfilling effect (i.e., when the urban plan is modified to integrate previous projection results) (Murdock et al., 1991). However, for methodological and data constraints, most small demographic projection models use traditional methods (Ballas, Clarke, et al., 2005; Birkin \& Clarke, 1989; Hamilton \& Perry, 1962; Institut de la statistique du Québec, 2010; Menthonnex, 2010; Rees, 1994; Rees, Norman, \& Brown, 2004; Simpson \& Tranmer, 2005; Swanson, Schlottmann, \& Schmidt, 2010). These challenges motivated us to develop the LDS with the goal of implementing contextual variables into a spatial microsimulation model.

\section{Local Demographic Simulations (LDS)}

LDS is a time-based microsimulation model that projects the population of the MMC's municipalities by age, sex, language spoken at home and immigrant status. It simulates processes and life events (e.g., mortality, fertility, residential mobility, etc.) of individuals following behavioral assumptions based on parameters derived from empirical data. The probability that each type of event occurs is calculated for each individual and the occurrence of a particular event is determined using a Monte Carlo process. Following the occurrence of an event, the characteristics of the simulated 
individual may change (life status can be changed to dead, place of residence can change, etc.). LDS can therefore be classified as a dynamic spatial microsimulation model as described by Tanton (2014). Because the model has been developed specifically for the Montreal Metropolitan Community, parameters cannot be directly applied for other metropolitan regions. However, the model could be replicated for other contexts by estimating new parameters that refer to the behaviour of the population studied on the condition that this data is available.

The starting population was extracted from the 2006 Census and reweighted using population estimates to account for the net census undercount. The projection's horizon is 2031. The simulation was run until 2011 and then, a second calibration was performed using the 2011 population estimates. LDS 1.0 and its parameters are described extensively in (add reference later). Most assumptions and processes of LDS 2.0 are the same as in LDS 1.0, but internal migration and residential location are modeled differently. The mortality risks, used in the official population projection published by the provincial statistics agency (Institut de la statistique du Québec), were adjusted using relative risks for individuals who were Canadian-born as well as for established immigrants and recent immigrants. Municipality-specific fertility rates by age and language spoken at home were estimated by combining simulations and the "own children method" applied to the 2006 Census data. An adaptation of the census based on a cross-sectional method developed by Sabourin and Bélanger (2011) was used to estimate intergenerational and intragenerational language shift rates. International emigration probabilities were estimated using attrition rates, while the net emigration rate 
for Canadian-born citizens was assumed to be null. Parameters from logistic regressions on the place of residence one year ago using pooled data from the 2001 and 2006 censuses were used to compute probabilities of interprovincial and intraprovincial outmigration. These probabilities were calibrated to ensure that the number of simulated outmigrants corresponded to the observed numbers for the 2006-2011period. The model also distinguishes between three different sources of external migrants: international inmigrants, interprovincial in-migrants and intraprovincial in-migrants. The projected levels for each of these inflows was taken from the official population projection of the Institut de la statistique du Québec (2009) which were determined from recent trends. Characteristics of these in-migrants were then randomly entered using a cold deck procedure based on a database of potential in-migrants created from the population living in the MMC at the time of the 2006 Census, but who were living elsewhere five years beforehand.

\section{Modeling internal migration and residential location with LDS 1.0}

The model LDS 1.0 is an innovative treatment of internal migration and residential location that combines elements from life cycle approach (Glick, 1947; Kim, Horner, \& Marans, 2005; Rossi, 1955) and the random utility model (Lee \& Waddell, 2010; McFadden, 1974, 1978) it also takes into account previous changes in local conditions when determining mobility and destination choices (Add reference later). Municipalities are first divided into two categories (the suburbs and the central core) to compute the location-specific probabilities of moving by age, language and place of birth. The destination choice of movers is then based on a utility function that accounts for contextual determinants of residential choice such as accessibility, development potential 
and linguistic composition of potential destinations. A similar function is used to estimate the allocation of a place of residence to the three types of external migrants. Parameters are estimated using conditional logistic regressions and are implemented into the microsimulation model. Assuming that migrants want to maximize the utility of attributes in the municipality they choose as their destination, this approach can be defined as follows: Let $U_{j}^{t}$ be a utility function for each possible alternative $\mathrm{j}$ for individuals of type $t$, where $t$ is the type of migrants (from the central municipality, from another suburb, from another country, from another province and from the rest of Quebec) and $\mathrm{j}$ the number of municipalities which has a set of $z_{n}$ characteristics. Thus, we have:

$U_{j}^{t}=e^{\beta_{1} z_{1 j}+\beta_{2} z_{2 j}+\ldots \beta_{n} z_{n j}}$

Where :

$U_{j}^{t}=$ Utility of a municipality $\mathrm{j}$ for a migrant type $\mathrm{t}, \mathrm{j}=1 \ldots \mathrm{J} ; \mathrm{t}=1 \ldots \mathrm{n}$

$z_{k j}=$ Value of the independent variable $\mathrm{k}$ for the municipality $\mathrm{j}, \mathrm{j}=1 \ldots \mathrm{J} ; \mathrm{k}=1 \ldots \mathrm{n}$

$\beta_{k}=$ Parameter of the independent variable $\mathrm{k}, \mathrm{k}=1 \ldots \mathrm{n}$

There are three types of internal migrants (from a suburb to the central municipality, from the central municipality to a suburb and from a suburb to another suburb), but only two need to be relocated following the utility function above, since there is only one municipality in the central area. In a prospective approach using different housing development plans, the main problem with LDS 1.0 is that migrants who are selected to move from the central municipality to the suburbs cannot consider their origin as a possible destination. Thus, assuming an increase in the number of new housing units in the central municipality will have no effect on the destination choice of these movers, 
since the only alternatives located in the suburbs are considered in the utility function. To solve this problem, we developed LDS 2.0 as described in the following section.

\section{Modeling internal migration and residential location with LDS 2.0}

In this new version, internal mobility is reduced to only one type of movement: moving within the metropolitan region, regardless of the origin or destination. Unlike in LDS 1.0, those who move within the same municipality are considered. The residential location of internal and external migrants is then determined according to a process similar to LDS 1.0 (following the random utility approach) except that they are stratified according to their life cycle rather than of their origin type. We, however, maintained a separate stratum for international immigrants because their location choice at their arrival in the metropolitan area differs greatly from those of internal migrants or migrants from elsewhere in Canada (Logan, Zhang, \& Alba, 2002). Thus, in LDS 2.0, the type t of migrants, as expressed in the utility equation presented previously, doesn't refer to the type of move anymore. Rather, $t$ types of migrants are then:

1. Those aged 0-4 and 25-34 together are the "young families";

2. Those aged 5-19 and 35-59 together are the "families";

3. Those aged 20-24 are "young adults";

4. Those aged 60 and over are the "seniors";

5. International immigrants at their arrival.

This method allows the migrant to consider the municipality of origin as a possible destination. According to this stratification, in-migrants from the rest of Canada and from the rest of Quebec don't have their own utility function. However, following the literature highlighting the importance of life cycles for the residential location, this stratification of 
the population should better identify individual preferences (Glick, 1947; Kim et al., 2005; Landale \& Guest, 1985; Rossi, 1955; South \& Crowder, 1997; Æro, 2006). LDS 2.0 therefore has 5 utility functions: one for each of the four life cycles described above and one for the international immigrants upon their arrival.

LDS 2.0 needs new assumptions concerning internal migration probabilities and residential locations. Parameters from a logistic regression on the question on the place of residence one year ago using pooled data from the 2001 and 2006 censuses were used to calculate moving probabilities within the metropolitan area. This takes into account everyone who changed address within the MMC, either because of a move in the same municipality or between different ones. Table 1 presents the model's estimated parameters. It shows that young adults and recent immigrants are more likely to move, in accordance with the literature (Logan et al., 2002; Rogers, Raquillet, \& Castro, 1978; Rossi, 1955). The "Regional County Municipality" (RCM of residence) variable parameters show that those living on the Island of Montreal (RCM66) are less likely to move than others.

\section{Insert table 1}

We then computed a municipality-specific intensity factor by dividing the expected number of movers by municipality estimated from the parameters by the number of movers observed in the censuses. This provides the user a control over regional and local parameters for prospective analysis purposes.

\footnotetext{
${ }^{2}$ County-like political entities
} 
Assumptions concerning the residential location modules were set using a similar method to the one described in LDS 1.0. For each stratum, parameters from conditional logic regressions using data from the question on the place of residence one year before the 2001 and 2006 censuses allowed us to implement the effect of contextual variables in the model. We tested several models using different combinations of available variables and selected the one that best predicted results for our projection. Parameters are presented in table 2 .

\section{Insert table 2}

The importance of the linguistic composition of municipalities on the residential choice is highlighted. For each stratum, the proportion of francophone's has a positive effect on francophone migrants, but a negative one on others. This is consistent with previous analysis on residential location (Add reference later). We also noticed that the number of new housing units is not a relevant variable for young adults, seniors and new immigrants, meaning that they are probably not likely to seek for new housing developments. This variable only affects the families and young families strata (the largest strata).

The modeling and assumptions concerning residential location in LDS 2.0 slightly differs from those of the previous version on a few points. Because the strata are not the same, the parameters are different. Additionally, the independent variables are also not exactly 
set the same way: we added variables on the presence of a highway and the proportion of immigrants (only for the "new immigrants" stratum) and we took the natural population size and the number of new housing units logarithm if this improved the model's performance. Another major difference concerned the implementation of a local contextual parameter. In version 1.0, an adjustment factor was set for some municipalities where the number of in-migrants was expected from simulations on 2001 and 2006 data which was very different from the observed number. In this new version, we objectively computed this adjustment factor which gave all the municipalities a contextual parameter. This adjustment factor was calculated by dividing the mean observed number of inmigrants for each stratum in the 2001 and 2006 censuses by the mean expected number using parameters from the conditional logistic regressions presented above in the 2001 and 2006 data. Therefore, the probability $\mathrm{P}$ of choosing a municipality $\mathrm{j}$ for a migrant type $\mathrm{t}$ in LDS 2.0 is formulated as follows:

$$
P_{j}^{t}=\frac{\delta_{j}^{t} * U_{j}^{t}}{\sum_{h=1}^{J} \delta_{h}^{t} * U_{h}^{t}}
$$

Where:

$U_{j}^{t}=$ Utility of a municipality $\mathrm{j}$ for a migrant type $\mathrm{t}, \mathrm{j}=1 \ldots \mathrm{J} ; \mathrm{t}=1 \ldots \mathrm{n}$;

$t^{\mathrm{o}}=$ Local contextual parameter of a municipality $\mathrm{j}$ for a migrant type $\mathrm{t}, \mathrm{j}=1 \ldots \mathrm{J} ; \mathrm{t}=1 \ldots \mathrm{n}$.

We should mention that under this model, housing units are not linked with individuals. They only act as a characteristic of each municipality, this variation over time may positively or negatively influence the destination choice of migrants. Other contextual factors, such as housing costs, economic trends and socio-economic composition could 
also influence this decision (Marois and Bélanger 2014), however they are not included in the estimate because it is impossible to make accurate and reliable assumptions on their dynamic and long-term evolution and cannot therefore be used in a prospective model.

\section{Assumptions concerning the future context}

Since the modeling of residential location depends on contextual variables, the projection model required assumptions concerning the future context. We therefore took into account the completion of Highway 30 on the south shore of Montreal in 2012 which changed the value of the variable for some municipalities and then we assumed that no new highway would be built. The main research question of this paper concerns the effect of the variable related to the number of new housing units in order to take into account different urban planning scenarios. For the 2006-2011 period, we used the observed annual number of new housing units (occupied or not) as reported in the 2006 and 2011 censuses. For the years beyond 2011, we established three scenarios. The number of new housing units in the reference scenario (A) which was taken directly from the MMC (Communauté métropolitaine de Montréal, 2007) development plan which provides estimates of housing development potential for each municipality until 2031. We also set an alternative scenario (B) in which the urban planning is much stricter and limits urban sprawl. In this scenario, the housing development potential is halved (divide by 2) for municipalities outside the Island of Montreal. The difference with scenario A (about 125,000 housing units over the projection period) as distributed to municipalities on the Island of Montreal following their respective population size in 2011. Scenario C is the opposite of scenario B. The number of new housing units on the Island of Montreal was 
halved and the difference with scenario $\mathrm{A}$ is distributed among the municipalities of the suburb following their population size in 2011 (about 14,000 housing units). This kind of scenario could occur if constraints on urban sprawl or land protection are released. The detailed assumptions are presented in Appendix 1. The plausibility of such alternative scenarios has however not been evaluated following the geographical and political context of concerned municipalities, however they show how the LDS model can be used in a prospective way to assess the impact of change in the urban plan on the geographical distribution of the population and on urban sprawl.

\section{Validation of the model}

Since the projection starts in 2006, we can validate the model by comparing the simulated population in 2011 (before the calibration) with available population estimates, following an approach inspired by Ballas, Clarke and Wiemers (2005). The detailed results of the simulation are presented in column 3 of Appendix 2. The absolute percent error for the MMC is very low, $0.2 \%$, which is not a surprise since most of the assumptions concerning population growth over this period for the entire region are derived from observed data. Table 3 presents the distribution of municipalities according to the absolute percent error. It reveals that the absolute percent error is quite low for most of the municipalities (below 5\% for 63 out of 79 municipalities). Overall, the mean percentage error for the 79 municipalities is $3.4 \%$. The highest absolute percent error is about $12 \%$ and the discrepancy is higher than $10 \%$ for only 3 municipalities, however two of them have populations below 2,000 inhabitants and other one has about 5,000 inhabitants, meaning that their gross error is still low considering that each projected 
individual represents about 5 people. These results are similar to those obtained with LDS 1.0, which performed very well (Add reference later).

Insert table 3

Table 4 presents the mean absolute percent error (MAPE) by population size of municipalities and population growth rate. It shows that the MAPE is lower for more populous municipalities. For areas with 50,000 inhabitants or more, the MAPE is $1.8 \%$, which is slightly higher than $4 \%$ for those with fewer than 15,000 inhabitants. We also calculated the MAPE detailing the population by 16 age groups. The same trends were observed, however MAPEs were logically higher due to increased volatility when population is disaggregated into smaller groups.

\section{Insert table 4}

We also calculated the MAPE according to the population growth rate between 2006 and 2011 (table 4). The MAPE seems slightly higher when the population growth rate is low, however the relation is not very conclusive since the differences are small. Additionally, there was a large heterogeneity in the distribution, since many municipalities with a low population growth rate also had a low absolute percent error.

Because the MAPE doesn't adequately penalise predictions that are relatively inaccurate, we also calculated the root mean square forecasting error (RMSFE), which was 1,796, which represents $3.7 \%$ of the average population size by municipality (about 48,000 ). 
This is comparable to the MAPE, meaning that there is no important over or underestimation in the simulated population.

To verify the presence of systematic errors, we also performed a Mincer-Zarnowitz (1969) regression on the results. This process tries to explain the observed population of municipalities from the simulated one. Because of the large variations in municipality population sizes, we used the log of the predicted and observed values, as suggested by Bollerslev and Wright (2001). The $\beta_{1}$ parameter resulting from this test was 0.997 which is not significantly different from 1 . While the $\beta_{0}$ parameter was 0.04 which is also not significantly different from 0 . This test revealed that the forecast is not systematically biased

\section{Results}

\section{Population trends for 2031}

The population growth rate for the entire metropolitan area is about the same (27\%) for all three scenarios, which was expected since the only difference between them concerns internal migration. The population of the metropolitan area will therefore gain about 1 million inhabitants, growing from 3.6 million in 2006 to 4.5 million in 2031. The results for the three scenarios are presented by municipality in Appendix 2. We began by looking at population trends for the reference scenario (scenario A), which is the expected scenario if housing development occurs in accordance with urban planning. Figure 1 presents the population growth rates by municipality for this scenario. 
Insert figure 1

It shows that the fastest growing municipalities are located on the North Shore (Mirabel (A on the map), Terrebonne (B), Sainte-Marthe-sur-le-Lac (C)) and the Vaudreuil region (D) as well as other municipalities located in areas including Contrecoeur (E), La Prairie (F) and Lery $(\mathrm{G})$. This is consistent with results produced using LDS 1.0 (Add reference later). According to the urban development plan on the number of new housing units, these municipalities all have a high development potential relative to their population size.

On the other hand, projected growth rates of most municipalities located on the Island of Montreal are very low and some are even negative. In most cases, the number of new housing units assumed by the plan is also very small relative to population size. The municipality of Montreal $(\mathrm{H})$ however, has a sizeable growth rate $(25.6 \%$, which is only slightly less than the MMC average). This is mainly because the city of Montreal is the destination of a large portion of landing immigrants. Some suburban municipalities also showed low growth rates since their development potential was also low, either because they are already fully urbanized or because they are located in protected agricultural areas.

\section{The impact of a change in urban planning assumptions}

Scenario B illustrates what would happen if urban planning seeks to restrain urban sprawl by halving the suburban development potential and increasing it on the Island of 
Montreal instead. Figure 2 shows the expected population growth rate by municipality between 2006 and 2031 for this scenario, while the map in Appendix 3 illustrates the relative difference in 2031 between the projected population of scenario A and scenario B.

Insert figure 2

In scenario B, the fastest growing municipalities located outside the Island of Montreal are the same as those in the reference scenario, however their growth rate is much lower. Only 5 show a growth rate of $50 \%$ or higher compared to 14 in scenario A (reference). At the opposite end of this spectrum, no municipalities on the Island of Montreal are declining in scenario B and, moreover, the growth rate of the municipality of Montreal would be much higher (37.7\% instead of $25.6 \%$ ). According this scenario, more people choose to stay in Montreal to found their family. Similar results can also be reported for other municipalities located on the Island of Montreal. The number of people living in the municipality of Montreal that we classified as "family" or "young family" is only 1 percentage point higher in scenario B than in the reference scenario $(69.9 \%$ vs $68.6 \%)$ and the mean age is 1.5 years lower however. Therefore, the impact on the age structure of this scenario appears quite small. This is caused by aging in place. More families stay in Montreal, but they also age there, subsequently increasing the number of elderly people. Change to internal mobility appears to affect population size rather than its age structure, which is consistent with studies on the impact of international immigration on 
population aging (Bijak, Kupiszewska, Kupiszewski, Saczuk, \& Kicinger, 2007; Coleman, 1992, 2008; Marois, 2008).

Urban sprawl is significantly reduced in scenario B, but the phenomenon remains still significant however because development potential remains high in some areas. Therefore, the growth rate of a municipality such as Mirabel is reduced compared to scenario A, moving from $77 \%$ to $51 \%$, but it still remains very high. This means that even with much stronger constraints in the residential development of low density suburbs, as in scenario B, urban sprawl would not be halted. Since the Montreal metropolitan region will face a significant growth in population over the coming years (about 1 million as mentioned previously), and since the space for new housing units on the Island of Montreal is limited because most of its sectors are already urbanized (Foggin \& Manzagol, 1998), it is hard to predict a plausible scenario where the number of new suburban housing units is reduced more than what was simulated for scenario B. This result appears to support the suggestion by Brueckner (2000), arguing that policies should also focus on the negative consequences of urban sprawl, since it cannot be reversed.

The last map (figure 3) presents the projected population growth rates by municipalities obtained from scenario $\mathrm{C}$, where the expected number of new housing units on the island of Montreal is halved with compensation in the suburbs. A map is included in Appendix 4, illustrating the relative differences in projected populations in 2031 comparing this scenario with scenario A. It illustrates the possible effect of reducing constraints on urban 
sprawl and land protection. To begin with, we noted that for many municipalities, there is virtually no difference compared to the reference scenario. This is because even though the development potential is halved on the Island of Montreal, the overall number of new housing units transferred from the Island to the suburbs is quite small (about 14 000); they come mainly from the municipality of Montreal and are distributed among a large number of municipalities (64). Some differences for small municipalities could therefore result from a Monte Carlo error rather than the assumptions on the number of new housing units. However, the results reveal that the number of rapidly growing municipalities would be higher where 23 out of 79 are expected to have a growth rate higher than 50\% from 2006 to 2031 under this scenario and all of them are located in the suburbs.

As observed in the reference scenario, scenario $\mathrm{C}$ shows that all the municipalities on the Island of Montreal either decline or show very small growth except for the municipality of Montreal itself which receives the majority of international immigrants. According to this finding, we can surmise that the loss of infrastructure efficiency caused by urban sprawl would be mitigated in the Montreal metropolitan area since the population in the central region is not declining - even when we assumed there would be a reduction in its residential development. However, in this scenario, the population growth rate for the municipality of Montreal (17.7\%) remains lower than the entire MMC (27.4\%), and is also lower than what is projected in the reference scenario $(25.5 \%)$. Furthermore, for scenario $\mathrm{B}$, the age structure of the central municipality is not significantly affected, since 
the proportion of people classified as "family" or "young family" is roughly the same as the reference scenario (68.5\% vs $68.6 \%)$, as well as the mean age (40.2 vs 41$)$.

\section{Insert figure 3}

Most of the suburban municipalities are expected to grow faster in scenario $\mathrm{C}$ than according to the reference scenario. This means that agricultural areas would be reduced and therefore, the negative consequences of urban sprawl could be more significant. On the other hand, future development could be different than in the past. Even if growth is significant in the suburbs, a higher density of new development could mitigate urban sprawl and its consequences (Beatley, 2000; Burton, Jenks, \& Williams, 2003; Daniels, 1999), except perhaps the problem caused by commuting to the downtown area where many jobs will likely continue to be located (Neuman, 2005).

\section{Conclusion}

One of the main challenges of small-area population projections is taking into account local conditions that can affect local population growth. Using the random utility approach to estimate the residential location, we developed the LDS model to help solve this challenge because it projects for population on a local level using contextual parameters. This paper presents an application of the model to assess the impact of change in urban planning in the Montreal Metropolitan Community. Since the expected number of new housing units is set as a parameter for the projection, the self-fulfilling effect often found in other small-area population projection models is avoided using 
LDS. Additionally, validation for the 2006-2011 period indicates that the performance of the model is satisfactory.

Three scenarios were set for the expected location of new housing units: a reference scenario, using data from the most recent urban plan as parameters; an alternative scenario, where the number of new housing units is halved in the suburbs and increased in the central core and another scenario that assumes there will be a reduction in residential development in the central area. Comparison of these scenarios shows the importance of taking into account the expected number of new housing units in a small area population projection model to properly project the population since the resulting population can differ widely by municipality between the three scenarios. Furthermore, as urban sprawl cannot be avoided, it also occurs in the scenario where there are much more constraints on residential development in the suburbs. It seems that only the pace of urban sprawl can be reduced. Therefore, policies should also try to reduce the negative consequences of urban sprawl. Our results show that the age structure of the Montreal municipality is not significantly affected by different mobility patterns.

The LDS 2.0 version used in this paper resolved some of the limitations in the previous version for prospective use. However, there are other limitations which remain. LDS 2.0 still doesn't allow for a finer geographical scale than by municipality. Technically, it would be possible to project on the neighborhood level, but the development potential from the MMC development plan used for the assumptions doesn't provide detailed estimates for this level. Moreover, multiplying the number of regions could burden the 
model and the computation time. Another limitation also comes from the source of the assumptions on the number of new housing units. Housing type was not taken into account in the utility function, whereas the literature highlights that one of the reasons to move concerns dwelling-size, especially for young families (Beatley, 2000; Karsten, 2007; Kestens, Thériault, \& Des Rosiers, 2007; Rossi, 1955; Rouwendal \& Meijer, 2001; South \& Crowder, 1997). This information is available in the census, but not in the development plan. Only the number of new homes is considered, regardless of type. Therefore, basing assumptions on the type of new housing units would not be founded on official and validated information.

Some of the limitations mentioned above could eventually be removed for further development of LDS but this would depend of the availability of data. Moreover, the abandonment of the long-form census in 2011 by the Federal Government could lead to poorer quality of estimates for further updates to LDS. The accessibility and the availability of data for researchers will therefore be an important issue in the future.

\section{Bibliography}

Ballas, D., Clarke, G. P., \& Wiemers, E. (2005). Building a dynamic spatial microsimulation model for Ireland. Population, Space and Place, 11(3), 157-172.

Ballas, D., Rossiter, D., Thomas, B., Clarke, G., \& Dorling, D. (2005). Geography Matters: Simulating the Local Impacts of National Social Policies. In J. R. Foundation (Ed.), (pp. 132). York: University of Leeds.

Barcelo, M., \& Trépanier, M.-O. (1999). Les indicateurs d'étalement urbain et de développement durable en milieu métropolitain Observatoire métropolitain de la région de Montréal.

Beatley, T. (2000). Green urbanism: Learning from European cities. Washington, DC: Island. 
Bergouignan, C. (2012). Prospective démographique localisée : de la diversité des méthodes à l'importance des données de recensement. Cahiers québécois de démographie, 41(2), 341-367.

Bijak, J., Kupiszewska, D., Kupiszewski, M., Saczuk, K., \& Kicinger, A. (2007). Population and labour force projections for 27 European countries, 2002-052: impact of international migration on population ageing. European Journal of Population / Revue européenne de Démographie, 23(1), 1-31.

Birkin, M., \& Clarke, M. (1989). The Generation of Individual and Household Incomes at the Small Area Level using Synthesis. Regional Studies, 23(6), 535-548.

Bollerslev, T. \& Wright, J. (2001). High-frequency data, frequency domain inference and volatility forecasting. Review of Economics and Statistics, 83, 596-602.

Brueckner, J. K. (2000). Urban Sprawl: Dignosis and Remedies. International Regional Science Review, 23(2), 160-171.

Burchell, R. W., G. Lowenstein, W. Dolphin, C., Galley, C., Downs, A., Seskin, S., . . Moore, T. (2002). The costs of sprawl-2000. Washington, DC: National Academy Press.

Burton, E., Jenks, M., \& Williams, K. (2003). The compact city: a sustainable urban form? : Routledge.

Cameron, M. P., \& Poot, J. (2011). Lessons from stochastic small-area population projections: the case of Waikato subregions in New Zealand. Journal of Population Research, 28(2-3), 245-265.

Chi, G., Zhou, X., \& Voss, P. R. (2011). Small-area population forecasting in an urban setting: a spatial regression approach. Journal of Population Research, 28(2-3), 185-201.

Coleman, D. A. (1992). Does Europe Need Immigrants? Population and Work Force Projections. International Migration Review, 26(2), 413-461.

Coleman, D. A. (2008). The demographic effects of international migration in Europe. Oxford Review of Economic Policy, 24(3), 452-476.

Communauté métropolitaine de Montréal. (2007). Identification des espaces disponibles à l'intérieur de la zone blanche et évaluation du potentiel d'accueil des municipalités de la Communauté métropolitaine de Montréal, volets 1 et 2, Rapport final (pp. 48 p.): Communauté métropolitaine de Montréal.

Daniels, T. (1999). When city and country collide: Managing growth in the metropolitan fringe. Washington, DC: Island.

Dittgen, A. (2008). Pourquoi et comment tenir compte du logement dans les projections de populations locales. Cahiers de démographie locale, 99-114.

Filion, S. (1993). L’étalement urbain, phénomène en évolution. En Bref, 4(2), 6-7.

Foggin, P., \& Manzagol, C. (1998). De la ville à la région urbain. In C. Manzagol \& C. Bryant (Eds.), Montréal 2001 : Visages et défis d'une métropole: Les Presses de l'Université de Montréal.

Foss, W. (2002). Small area population forecasting. Appraisal Journal, 70(2), 163-172. Glick, P. C. (1947). The Family Cycle. American Sociological Review, 12(2), 164-174. Hamilton, C. H., \& Perry, J. (1962). A Short Method for Projecting Population By Age from One Decennial Census to Another. Social Forces, 41(2), 163-170. 
Harding, A., Vidyattama, Y., \& Tanton, R. (2011). Demographic change and the needsbased planning of government services: projecting small area populations using spatial microsimulation. Journal of Population Research, 28(2-3), 203-224.

Huard, A.-M., Deshaies, M.-È., \& Garand, G. (2010). Bilan de la situation des milieux humides de Laval (pp. 7 p.). Conseil régional de l'environnement de Laval.

Institut de la statistique du Québec. (2009). Perspectives démographiques du Québec et des régions, 2006-2056, Édition 2009. Québec: Institut de la statistique du Québec.

Institut de la statistique du Québec. (2010). Projection de la population des municipalités, 2009-2024. Retrieved from http://www.stat.gouv.qc.ca/donstat/societe/demographie/persp_poplt/index.htm\# municipalit\%C3\%A9s.

Isserman, A. M. (1984). Projection, Forecast, and Plan On the Future of Population Forecasting. Journal of the American Planning Association, 50(2), 208-221.

Kanaroglou, P. S., Maoh, H. F.,Newbold, B. Scott, D. M. \& Paez, A. (2009). A demographic model for small area population projections: an application to the Census Metropolitan Area of Hamilton in Ontario, Canada. Environment and Planning A, 41(4), 964-979.

Karsten, L. (2007). Housing as a Way of Life: Towards an Understanding of MiddleClass Families' Preference for an Urban Residential Location. Housing Studies, 22(1), 83-98.

Kestens, Y., Thériault, M., \& Des Rosiers, F. (2007). Choix résidentiels des ménages lors de l'acquisition d'une maison unifamiliale. In M. Thériault \& F. Des Rosiers (Eds.), Information géographique et dynamiques urbaines 1: Hermès - Lavoisier.

Keyfitz, N. (1972). On Future Population. Journal of the American Statistical Association, 67(338), 347-363.

Kim, T.-K., Horner, M. W., \& Marans, R. W. (2005). Life Cycle and Environmental Factors in Selecting Residential and Job Locations. Housing Studies, 20(3), 457473.

Landale, N. S., \& Guest, A. M. (1985). Constraints, Satisfaction and Residential Mobility: Speare's Model Reconsidered. Demography, 22(2), 199-222.

Lee, B., H. Y., \& Waddell, P. (2010). Residential mobility and location choice: a nested logit model with sampling of alternatives. Transportation, 37(4), 587-601.

Logan, J. R., Zhang, W., \& Alba, R. D. (2002). Immigrant Enclaves and Ethnic Communities in New York and Los Angeles. American Sociological Review, 67(2), 299-322.

Lutz, W. (2009). Toward a systematic, argument-based approach to defining assumptions for population projections: Laxenburg: International Institute for Applied Systems Analysis.

Marois, G. (2008). La migration de remplacement : un exercice méthodologique en rapport aux enjeux démographiques du Québec. Cahiers québécois de démographie, 37(2), 237-261.

Marois, G. \& Bélanger, A. (2014). Déterminants du choix du lieu de résidence dans la banlieue de Montréal : perspective du cycle de vie et ségrégation. Cahiers québécois de démographie, 43(2). 
McFadden, D. (1974). Conditional Logit Analysis of Qualitative Choice Behavior. In P. Zarembka (Ed.), Frontiers in Econometrics. New York: Academic Press.

McFadden, D. (1978). Modelling the Choice of Residential Location. In A. Karlqvist et al. (Eds.), Spatial Interaction Theory and Planning Models. Amsterdam.

Menthonnex, J. (2010). Perspectives démographiques pour le canton de Vaud. Cahiers de démographie locale, 149-183.

Mincer, J. \& Zarnowitz, V. (1969). The Evaluation of Economic Forecasts. In J. Mincer (Ed.), Economic Forecasts and Expectations. National Bureau of Economic Research, New York.

Montminy, D. (2010). La protection du territoire agricole de la région métropolitaine de recensement (RMR) de Montréal dans un contexte d'étalement urbain. (M.Sc.), Université de Montréal, Montréal.

Murdock, S. H., Hamm, R. R., Voss, P. R., Fannin, D., \& Pecotte, B. (1991). Evaluating Small-Area Population Projections. Journal of the American Planning Association, 57(4), 432-443.

Nechyba, T. J., \& Walsh, R. P. (2004). Urban Sprawl. The Journal of Economic Perspectives, 18(4), 177-200.

Neuman, M. (2005). The compact city fallacy. Journal of planning education and research, 25(1), 11-26.

Rees, P. (1994). Estimating and projecting the populations of urban communities. Environment and Planning A, 26(11), 1671-1697.

Rees, P., Norman, P., \& Brown, D. (2004). A framework for progressively improving small area population estimates. Journal of the Royal Statistical Society: Series A (Statistics in Society), 167(1), 5-36.

Roberts, W. (2001). The Way to a City's Heart is Through its Stomach: Putting Food Security on the Urban Planning Menu. Crackerbarrel Philosophy Series.

Rogers, A., Raquillet, R., \& Castro, L. J. (1978). Model migration schedules and their applications. Environment and Planning A, 10(5), 475-502.

Rossi, P. H. (1955). Why Families Move. Beverly Hills: Sage.

Rouwendal, J., \& Meijer, E. (2001). Preferences for Housing, Jobs, and Commuting: A Mixed Logit Analysis. Journal of Regional Science, 41(3), 475-505.

Sabourin, P., \& Bélanger, A. (2011). Microsimulation of language use at home in a multilingual region with high immigration. Paper presented at the 3rd General Conference of the International Microsimulation Association, Stockholm, Sweden.

Simpson, L., \& Tranmer, M. (2005). Combining Sample and Census Data in Small Area Estimates: Iterative Proportional Fitting with Standard Software*. The Professional Geographer, 57(2), 222-234.

South, S. J., \& Crowder, K. D. (1997). Residential mobility between cities and suburbs: race, suburbanization, and back-to-the-city moves. Demography, 34(4), 525-538.

Swanson, D. A., \& Pol, L. (2008). Applied demography: Its business and public sector components. In Y. Zeng (Ed.), The Encyclopedia of Life Support Systems, Demography Volume. Oxford, England.: UNESCO-EOLSS Publishers.

Swanson, D. A., Schlottmann, A., \& Schmidt, B. (2010). Forecasting the Population of Census Tracts by Age and Sex: An Example of the Hamilton-Perry Method in Action. Population Research and Policy Review, 29(1), 47-63. 
Tanton, R. (2014). A Review of Spatial Microsimulation Methods. International Journal of Microsimulation, 7(1), 4-25.

Umbelino, G. (2012). Simulations of household spatial distribution and intraurban demographic projections supported by geotecnologie. (Ph. D. in Demography), Federal University of Minas Gerais, Belo Horizonte, Brazil.

Waddell, P. (2000). A behavioral simulation model for metropolitan policy analysis and planning: residential location and housing market components of UrbanSim. Environment and Planning B, 27(2), 247-264.

Waddell, P. (2002). UrbanSim: Modeling urban development for land use, transportation, and environmental planning. Journal of the American Planning Association, 68(3), 297-314.

Wilson, T. (2011). A Review of Sub-Regional Population Projection Methods: Queensland Centre for Population Research, School of Geography, Planning and Environmental Management, The University of Queensland

Ero, T. (2006). Residential Choice from a Lifestyle Perspective. Housing, Theory and Society, 23(2), 109-130. 
Table 1

Logistic regressions parameters modeling internal migration in the Montreal Metropolitan Community using the 2001 and 2006

Censuses $(\mathbf{n}=\mathbf{5 8 6 , 1 5 1})$

\begin{tabular}{|c|c|c|}
\hline \multirow{2}{*}{\multicolumn{3}{|c|}{$\begin{array}{l}\text { Intercept } \\
\text { Age groups (ref=30-34) }\end{array}$}} \\
\hline & & \\
\hline $0-4$ & -0.190 & $* * *$ \\
\hline $5-9$ & -0.558 & $* * *$ \\
\hline $10-14$ & -0.826 & $* * *$ \\
\hline $15-19$ & -0.691 & $* * *$ \\
\hline $20-24$ & 0.318 & $* * *$ \\
\hline $25-29$ & 0.446 & $* * *$ \\
\hline $35-39$ & -0.371 & $* * *$ \\
\hline $40-44$ & -0.692 & $* * *$ \\
\hline $45-49$ & -0.900 & $* * *$ \\
\hline $50-54$ & -1.029 & $* * *$ \\
\hline $55-59$ & -1.146 & $* * *$ \\
\hline $60-64$ & -1.297 & $* * *$ \\
\hline $65-69$ & -1.435 & $* * *$ \\
\hline $70-74$ & -1.556 & $* * *$ \\
\hline $75+$ & -1.417 & $* * *$ \\
\hline \multicolumn{3}{|c|}{ Language spoken at home (ref=French) } \\
\hline English & -0.238 & $* * *$ \\
\hline Other(s) & -0.297 & $* * *$ \\
\hline \multicolumn{3}{|c|}{ Number of years since arrival (ref=Born in Canada) } \\
\hline $0-4$ & 0.641 & $* * *$ \\
\hline $5-9$ & 0.171 & $* * *$ \\
\hline $10-14$ & -0.031 & \\
\hline $15+$ & -0.284 & $* * *$ \\
\hline \multicolumn{3}{|c|}{$\mathrm{RCM}$ of residence $(\mathrm{ref}=\mathrm{RCM} 66)$} \\
\hline RCM55 and RCM57 & -0.428 & $* * *$ \\
\hline RCM58 & -0.234 & $* * *$ \\
\hline RCM59 & -0.525 & $* * *$ \\
\hline RCM60 & -0.443 & $* * *$ \\
\hline RCM64 & -0.486 & $* * *$ \\
\hline RCM65 & -0.352 & $* * *$ \\
\hline RCM67 and RCM70 & -0.470 & $* * *$ \\
\hline RCM71 & -0.442 & $* * *$ \\
\hline RCM72 & -0.388 & $* * *$ \\
\hline RCM73 and RCM74 & -0.427 & $* * *$ \\
\hline
\end{tabular}

$* \mathrm{p}<0.05$

$* * \mathrm{p}<0.01$

$* * * \mathrm{p}<0.0001$ 
Table 2

Parameters of conditional logistic regression modeling the municipality of destination for internal and external migrants, Montreal Metropolitan Community, 2001 and 2006 Censuses

\begin{tabular}{|c|c|c|c|c|c|}
\hline & $\begin{array}{l}\text { Young families } \\
\quad(n=52,167)\end{array}$ & $\begin{array}{c}\text { Families } \\
(\mathrm{n}=76,889)\end{array}$ & $\begin{array}{l}\text { Young adults } \\
(\mathrm{n}=22,414)\end{array}$ & $\begin{array}{c}\text { Seniors } \\
(\mathrm{n}=12,427)\end{array}$ & $\begin{array}{c}\text { New } \\
\text { immigrants } \\
(n=14,993)\end{array}$ \\
\hline Presence of a highway & $0.170 * * *$ & $0.215 * * *$ & $0.218 * * *$ & & \\
\hline Distance to downtown area $(\mathrm{km})$ & $-0.012 * * *$ & $-0.004 * *$ & $-0.011 * *$ & $-0.021 * * *$ & $-0.021 * * *$ \\
\hline Population size & & $1.344 \mathrm{E}-07 * * *$ & $4.327 \mathrm{E}-07 * * *$ & $-1.481 \mathrm{E}-07 * *$ & $8.840 \mathrm{E}-07 * * *$ \\
\hline $\ln ($ Population size $)$ & $1.148 * * *$ & $0.980 * * *$ & $1.125 * * *$ & $1.055 * * *$ & $0.784 * * *$ \\
\hline New housing units & $2.880 \mathrm{E}-05 * * *$ & & & & \\
\hline $\ln$ (New housing units) & & $0.091 * * *$ & & & \\
\hline Proportion of francophones & $2.367 * * *$ & $2.141 * * *$ & $2.481 * * *$ & $2.186 * * *$ & $1.191 * * *$ \\
\hline *anglophone migrant & $-5.911 * * *$ & $-5.830 * * *$ & $-6.221 * * *$ & $-6.618 * * *$ & $-3.849 * * *$ \\
\hline *allophone migrant & $-4.995 * * *$ & $-4.727 * * *$ & $-4.995 * * *$ & $-4.062 * * *$ & $-2.069 * * *$ \\
\hline Proportion of immigrants & & & & & $2.645 * * *$ \\
\hline $\begin{array}{l}\mathrm{RCM} \text { of residence }(\mathrm{ref}=\mathrm{RCM} 65 \\
\text { and } \mathrm{RCM} 66)\end{array}$ & & & & & \\
\hline RCM55 and RCM57 & $0.510 * * *$ & $0.243 * * *$ & $0.217 * *$ & -0.136 & $-0.666 * * *$ \\
\hline RCM58 & $0.057 *$ & $0.129 * * *$ & $0.236 * * *$ & $-0.114 *$ & $0.430 * * *$ \\
\hline RCM59 & $0.336 * * *$ & -0.068 & -0.020 & $-0.736 * * *$ & $-0.824 * * *$ \\
\hline RCM60 & $0.093 *$ & -0.027 & -0.065 & $0.216 * *$ & $-0.979 * * *$ \\
\hline RCM64 & $0.231 * * *$ & $-0.070 *$ & 0.103 & -0.054 & $-1.151 * * *$ \\
\hline RCM67 and RCM70 & $0.384 * * *$ & $0.147 * * *$ & $0.296 * * *$ & $-0.207 * *$ & $-1.353 * * *$ \\
\hline RCM71 & $1.003 * * *$ & $0.557 * * *$ & $0.682 * * *$ & $0.512 * * *$ & -0.037 \\
\hline RCM72 & $0.394 * * *$ & $0.194 * * *$ & $0.436 * * *$ & $0.187 *$ & $-0.601 * *$ \\
\hline RCM73 and RCM74 & $0.460 * * *$ & $0.178 * * *$ & $0.335 * * *$ & 0.015 & $-0.539 * * *$ \\
\hline
\end{tabular}

$* \mathrm{p}<0.05$

$* * \mathrm{p}<0.01$

$* * * \mathrm{p}<0.0001$ 
Table 3

\section{Distribution of}

municipalities according to

the absolute percent error

\begin{tabular}{lc}
\hline$[10 \%, \infty[$ & 3 \\
{$[5 \%, 10 \%[$} & 13 \\
{$[2.5 \%, 5 \%[$} & 28 \\
{$[0,2.5 \%[$} & 35 \\
\hline
\end{tabular}

Table 4

Mean percent error in 2011 between the population estimates and the pre-simulation (absolute value)

\begin{tabular}{lcc}
\hline & Whole population & $\begin{array}{c}\text { Population by age } \\
\text { groups (16) }\end{array}$ \\
\hline $\begin{array}{l}\text { By population size of } \\
\text { municipalities }\end{array}$ & & \\
\hline$[50,000, \infty[$ & $1.8 \%$ & $6.3 \%$ \\
{$[15,000,50,000[$} & $2.9 \%$ & $9.4 \%$ \\
{$[5,000,15,000[$} & $4.1 \%$ & $14.1 \%$ \\
{$[0,5,000[$} & $4.1 \%$ & $20.2 \%$ \\
\hline By population growth rate & & \\
between 2006-2011 & & \\
\hline$[10 \%, \infty[$ & $2.8 \%$ & $11.3 \%$ \\
{$[5 \%, 10 \%[$} & $3.4 \%$ & $10.9 \%$ \\
{$[0 \%, 5 \%[$} & $3.9 \%$ & $13.9 \%$ \\
]$-\infty, 0 \%[$ & $4.1 \%$ & $14.9 \%$ \\
\hline
\end{tabular}


Figure 1

Projected population growth rates by municipality, scenario A, MMC, 2006 to 2031

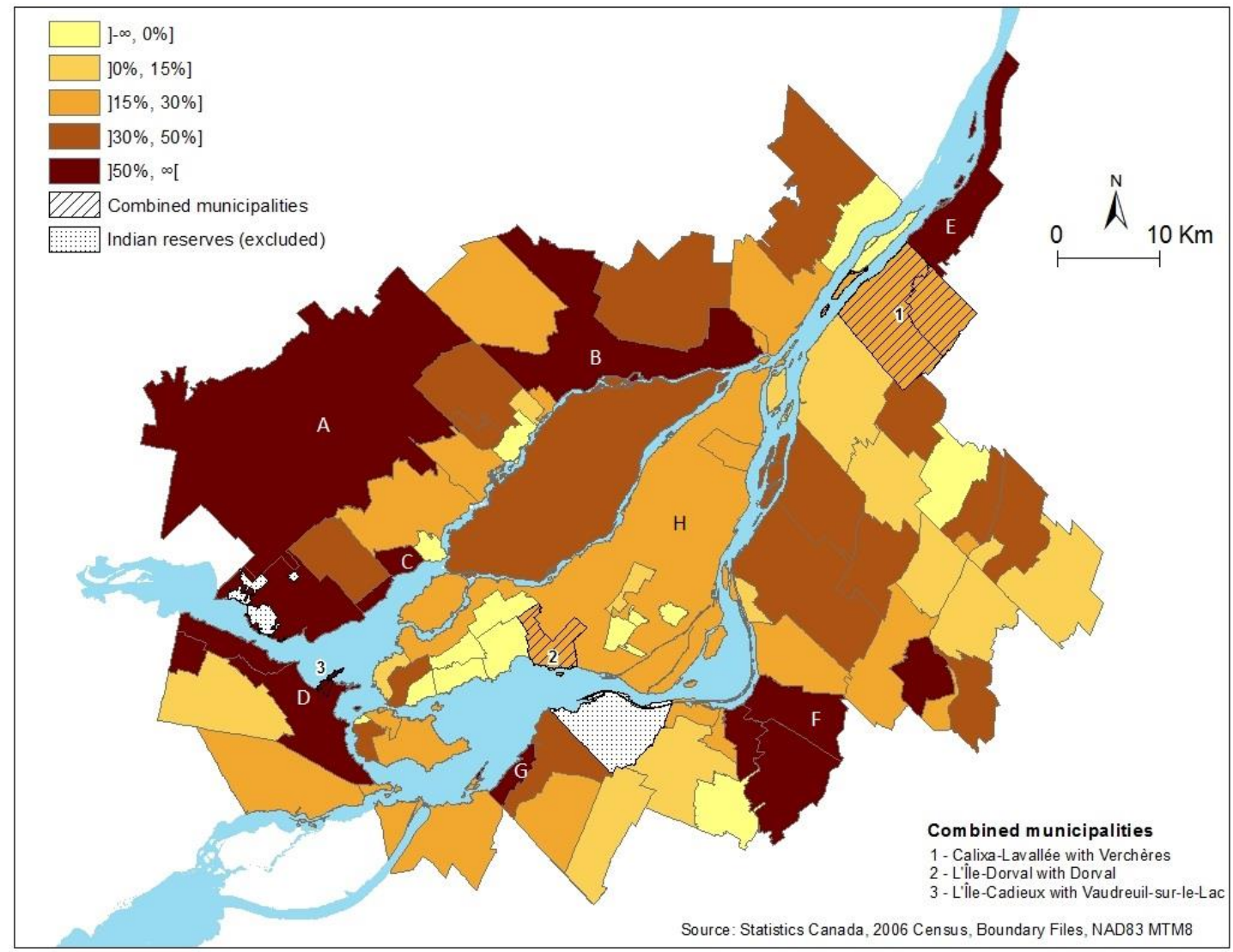


Figure 2

Projected population growth rates by municipality, scenario B, MMC, 2006 to 2031




Figure 3

Projected population growth rates by municipality, scenario C, MMC, 2006 to 2031

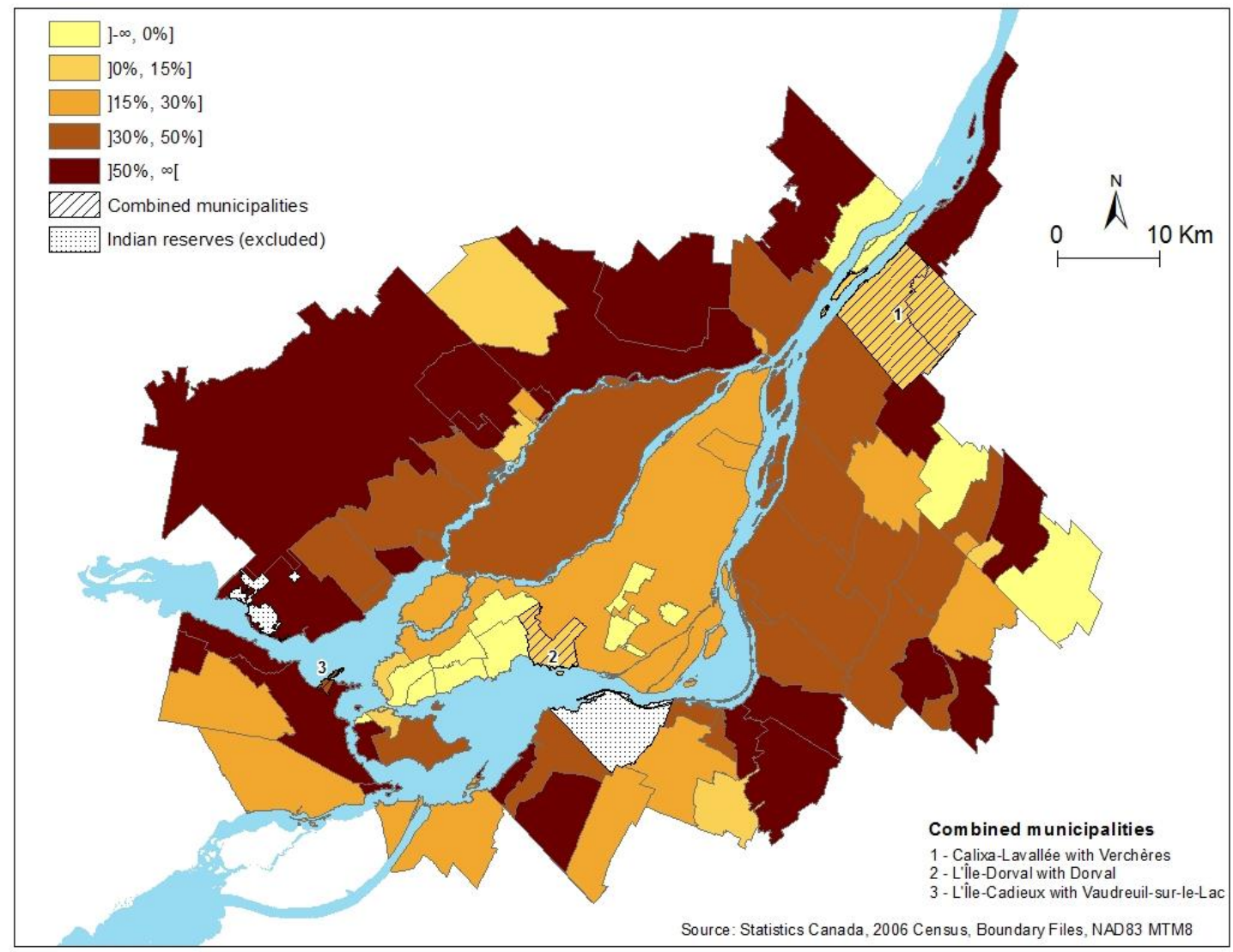


Appendix 1

Assumptions on the number of new housing units

\begin{tabular}{|c|c|c|c|c|c|}
\hline \multirow[t]{2}{*}{ Municipalities } & \multirow{2}{*}{$\begin{array}{l}\text { Location } \\
\text { (I=Island of } \\
\text { Montreal; } \\
\text { S=Suburb) }\end{array}$} & \multirow{2}{*}{\begin{tabular}{|c|} 
Annual \\
number of \\
new housing \\
units, 2006 to \\
2011 \\
\end{tabular}} & \multicolumn{3}{|c|}{$\begin{array}{l}\text { Annual number of new housing units, } \\
2011 \text { to } 2031\end{array}$} \\
\hline & & & Scenario A & Scenario B & Scenario C \\
\hline Baie-D'Urfé & I & 0 & 1 & 5 & 0 \\
\hline Beaconsfield & I & 12 & 13 & 37 & 6 \\
\hline Beauharnois & S & 66 & 21 & 10 & 26 \\
\hline Beloeil & S & 194 & 70 & 35 & 79 \\
\hline Blainville & S & 575 & 84 & 42 & 108 \\
\hline Boisbriand & $S$ & 104 & 12 & 6 & 24 \\
\hline Bois-des-Filion & S & 120 & 0 & 0 & 4 \\
\hline Boucherville & S & 268 & 120 & 60 & 138 \\
\hline Brossard & S & 914 & 43 & 22 & 79 \\
\hline Candiac & S & 293 & 11 & 5 & 20 \\
\hline Carignan & S & 40 & 45 & 22 & 48 \\
\hline Chambly & S & 271 & 59 & 30 & 71 \\
\hline Charlemagne & S & 50 & 2 & 1 & 5 \\
\hline Châteauguay & S & 367 & 186 & 93 & 207 \\
\hline Contrecoeur & S & 92 & 54 & 27 & 57 \\
\hline Côte-Saint-Luc & I & 0 & 10 & 50 & 5 \\
\hline Delson & $S$ & 26 & 22 & 11 & 26 \\
\hline Deux-Montagnes & S & 41 & 0 & 0 & 8 \\
\hline Dollard-Des Ormeaux & I & 69 & 0 & 60 & 0 \\
\hline Dorval et L'Île-Dorval & I & 75 & 27 & 50 & 14 \\
\hline Hampstead & I & 3 & 0 & 9 & 0 \\
\hline Hudson & S & 14 & 223 & 111 & 225 \\
\hline Kirkland & I & 44 & 0 & 25 & 0 \\
\hline La Prairie & S & 118 & 103 & 52 & 114 \\
\hline L'Assomption & S & 333 & 7 & 3 & 15 \\
\hline Laval & S & 2,273 & 688 & 344 & 866 \\
\hline Léry & S & 5 & 46 & 23 & 47 \\
\hline Les Cèdres & S & 49 & 9 & 4 & 11 \\
\hline L'T̂le-Perrot & S & 66 & 12 & 6 & 17 \\
\hline Longueuil & S & 951 & 629 & 315 & 733 \\
\hline Lorraine & S & 9 & 5 & 3 & 10 \\
\hline Mascouche & S & 778 & 30 & 15 & 48 \\
\hline McMasterville & S & 30 & 0 & 0 & 2 \\
\hline Mercier & S & 144 & 0 & 0 & 5 \\
\hline Mirabel & S & 643 & 275 & 137 & 293 \\
\hline Montréal & I & 5,352 & 1,432 & 3,466 & 716 \\
\hline Montréal-Est & I & 15 & 0 & 5 & 0 \\
\hline
\end{tabular}




\begin{tabular}{|c|c|c|c|c|c|}
\hline Montréal-Ouest & I & 0 & 1 & 7 & 0 \\
\hline Mont-Royal & I & 3 & 2 & 26 & 1 \\
\hline Mont-Saint-Hilaire & $\mathrm{S}$ & 216 & 23 & 11 & 30 \\
\hline Notre-Dame-de-l'Île-Perrot & $\mathrm{S}$ & 62 & 45 & 22 & 49 \\
\hline Oka & $S$ & 53 & 16 & 8 & 17 \\
\hline Otterburn Park & $S$ & 23 & 26 & 13 & 30 \\
\hline Pincourt & $S$ & 209 & 67 & 33 & 73 \\
\hline Pointe-Calumet & $\mathrm{S}$ & 0 & 39 & 19 & 41 \\
\hline Pointe-Claire & I & 0 & 34 & 72 & 17 \\
\hline Pointe-des-Cascades & $\mathrm{S}$ & 31 & 4 & 2 & 5 \\
\hline Repentigny & $\mathrm{S}$ & 646 & 14 & 7 & 49 \\
\hline Richelieu & $\mathrm{S}$ & 29 & 0 & 0 & 2 \\
\hline Rosemère & $S$ & 37 & 8 & 4 & 14 \\
\hline Saint-Amable & $\mathrm{S}$ & 214 & 0 & 0 & 5 \\
\hline Saint-Basile-le-Grand & $\mathrm{S}$ & 84 & 0 & 0 & 7 \\
\hline Saint-Bruno-de-Montarville & $S$ & 155 & 67 & 33 & 78 \\
\hline Saint-Constant & $S$ & 128 & 60 & 30 & 71 \\
\hline Sainte-Anne-de-Bellevue & I & 14 & 64 & 71 & 32 \\
\hline Sainte-Anne-des-Plaines & $S$ & 111 & 10 & 5 & 16 \\
\hline Sainte-Catherine & $\mathrm{S}$ & 96 & 0 & 0 & 7 \\
\hline Sainte-Julie & $S$ & 82 & 8 & 4 & 21 \\
\hline Sainte-Marthe-sur-le-Lac & $\mathrm{S}$ & 341 & 65 & 33 & 72 \\
\hline Sainte-Thérèse & $\mathrm{S}$ & 102 & 0 & 0 & 12 \\
\hline Saint-Eustache & $S$ & 248 & 58 & 29 & 77 \\
\hline Saint-Isidore & $S$ & 16 & 0 & 0 & 1 \\
\hline Saint-Jean-Baptiste & $S$ & 21 & 0 & 0 & 1 \\
\hline Saint-Joseph-du-Lac & $S$ & 106 & 15 & 7 & 18 \\
\hline Saint-Lambert & $S$ & 0 & 0 & 0 & 10 \\
\hline Saint-Lazare & $S$ & 156 & 78 & 39 & 86 \\
\hline Saint-Mathias-sur-Richelieu & $S$ & 19 & 0 & 0 & 2 \\
\hline Saint-Mathieu & $\mathrm{S}$ & 3 & 0 & 0 & 1 \\
\hline Saint-Mathieu-de-Beloeil & $\mathrm{S}$ & 25 & 2 & 1 & 3 \\
\hline Saint-Philippe & $S$ & 32 & 44 & 22 & 46 \\
\hline Saint-Sulpice & $\mathrm{S}$ & 17 & 0 & 0 & 1 \\
\hline Senneville & I & 0 & 1 & 2 & 1 \\
\hline Terrasse-Vaudreuil & $S$ & 3 & 0 & 0 & 1 \\
\hline Terrebonne & $S$ & 885 & 934 & 467 & 981 \\
\hline Varennes & $\mathrm{S}$ & 58 & 0 & 0 & 9 \\
\hline Vaudreuil-Dorion & $\mathrm{S}$ & 531 & 298 & 149 & 312 \\
\hline Vaudreuil-sur-le-Lac et L'Île- & $S$ & 15 & 15 & 8 & 16 \\
\hline Verchères et Calixa-Lavallée & $S$ & 89 & 0 & 0 & 3 \\
\hline Westmount & I & 7 & 0 & 25 & 0 \\
\hline
\end{tabular}


Appendix 2

Results of simulations and population estimates

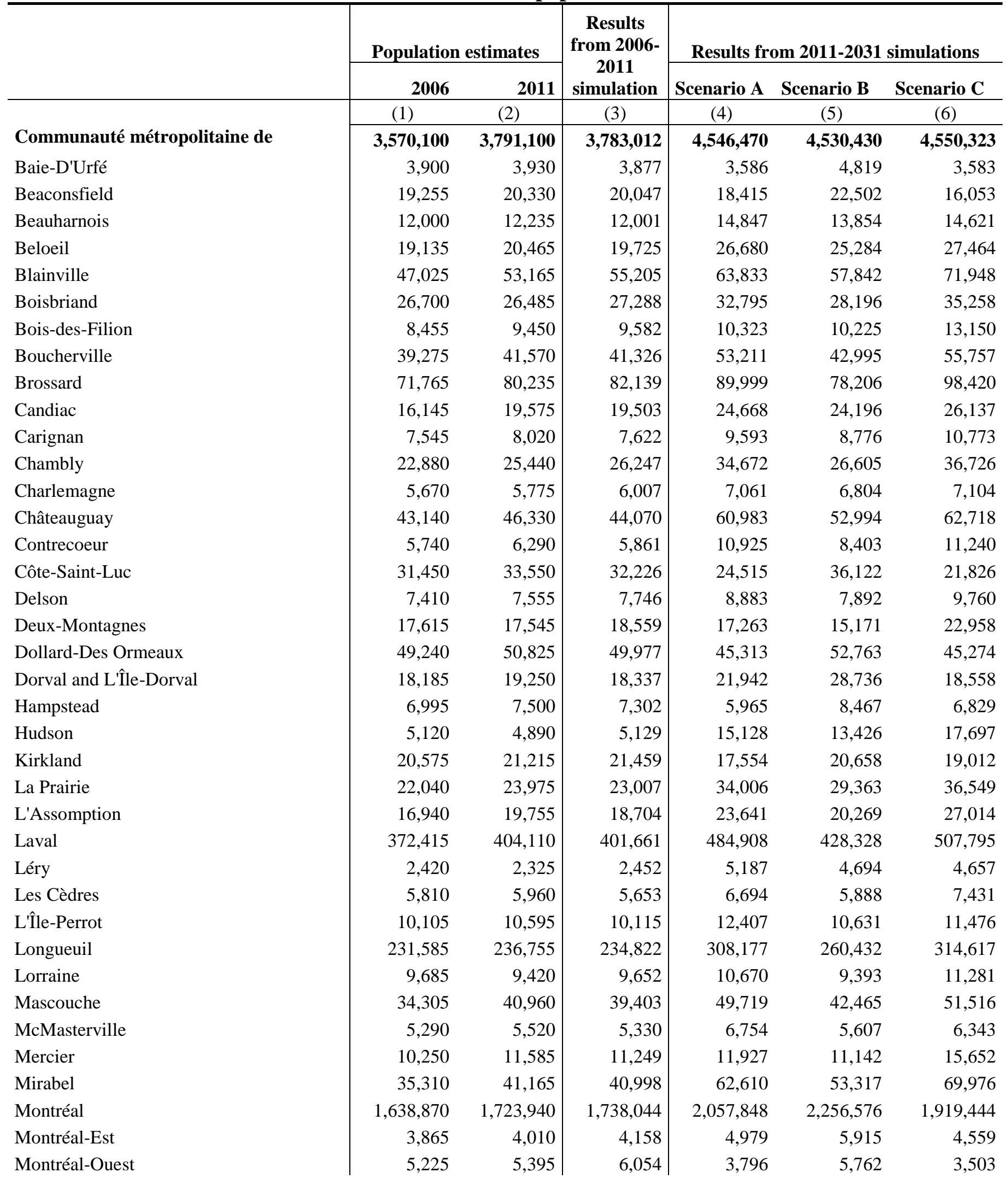


Mont-Royal

Mont-Saint-Hilaire

Notre-Dame-de-l'Île-Perrot

Oka

Otterburn Park

Pincourt

Pointe-Calumet

Pointe-Claire

Pointe-des-Cascades

Repentigny

Richelieu

Rosemère

Saint-Amable

Saint-Basile-le-Grand

Saint-Bruno-de-Montarville

Saint-Constant

Sainte-Anne-de-Bellevue

Sainte-Anne-des-Plaines

Sainte-Catherine

Sainte-Julie

Sainte-Marthe-sur-le-Lac

Sainte-Thérèse

Saint-Eustache

Saint-Joseph-du-Lac

Saint-Lambert

Saint-Lazare

Saint-Mathias-sur-Richelieu

Saint-Mathieu

Saint-Mathieu-de-Beloeil

Saint-Philippe

Saint-Sulpice

Senneville

Terrasse-Vaudreuil

Terrebonne

Varennes

Vaudreuil-Dorion

Vaudreuil-sur-le-Lac and L'Île-Cadieux

Verchères and Calixa-Lavallée

Westmount
Saint-Isidore

Saint-Jean-Baptiste

\begin{tabular}{|c|c|c|c|c|c|}
\hline 18,995 & 20,225 & 18,716 & 19,877 & 21,029 & 18,861 \\
\hline 15,865 & 17,410 & 17,057 & 22,478 & 18,487 & 26,195 \\
\hline 10,030 & 10,430 & 10,086 & 12,407 & 10,974 & 13,385 \\
\hline 3,310 & 3,700 & 3,609 & 5,693 & 4,423 & 5,497 \\
\hline 8,580 & 8,470 & 8,392 & 9,594 & 9,548 & 9,394 \\
\hline 11,375 & 13,690 & 13,334 & 16,700 & 13,238 & 17,651 \\
\hline 6,645 & 6,455 & 6,761 & 10,007 & 7,763 & 9,682 \\
\hline 30,275 & 31,875 & 30,091 & 28,848 & 41,474 & 22,967 \\
\hline 1,045 & 1,195 & 1,208 & 1,305 & 1,698 & 1,574 \\
\hline 77,035 & 81,275 & 79,458 & 89,336 & 80,829 & 100,837 \\
\hline 5,240 & 5,335 & 5,760 & 7,224 & 6,036 & 8,751 \\
\hline 14,290 & 14,070 & 13,583 & 13,827 & 12,884 & 14,636 \\
\hline 8,510 & 10,620 & 9,991 & 11,369 & 12,177 & 14,143 \\
\hline 15,825 & 16,550 & 16,587 & 17,748 & 16,421 & 20,765 \\
\hline 24,515 & 25,965 & 25,331 & 35,589 & 30,762 & 36,392 \\
\hline 24,250 & 24,990 & 24,214 & 27,610 & 25,151 & 30,220 \\
\hline 5,235 & 5,425 & 4,983 & 7,264 & 9,837 & 4,385 \\
\hline 13,165 & 13,730 & 14,226 & 15,342 & 13,049 & 15,006 \\
\hline 16,405 & 16,885 & 17,245 & 21,229 & 18,610 & 23,679 \\
\hline 29,380 & 29,095 & 28,135 & 32,244 & 28,584 & 37,270 \\
\hline 11,485 & 14,840 & 15,047 & 20,124 & 16,303 & 20,930 \\
\hline 25,490 & 26,140 & 25,819 & 35,115 & 30,098 & 43,659 \\
\hline 42,610 & 43,525 & 43,432 & 52,933 & 48,044 & 58,260 \\
\hline 2,520 & 2,640 & 2,682 & 2,526 & 2,797 & 3,267 \\
\hline 3,060 & 3,090 & 2,805 & 3,223 & 3,140 & 3,059 \\
\hline 5,035 & 6,245 & 5,764 & 7,130 & 6,010 & 7,274 \\
\hline 21,660 & 22,015 & 20,138 & 23,477 & 20,695 & 29,136 \\
\hline 17,260 & 18,980 & 18,807 & 17,560 & 17,387 & 20,123 \\
\hline 4,570 & 4,465 & 4,571 & 4,637 & 5,218 & 5,794 \\
\hline 1,890 & 1,990 & 1,768 & 1,841 & 2,294 & 1,902 \\
\hline 2,315 & 2,545 & 2,540 & 2,073 & 1,904 & 2,173 \\
\hline 5,180 & 5,630 & 5,637 & 9,395 & 7,460 & 9,311 \\
\hline 3,355 & 3,290 & 3,140 & 2,874 & 2,636 & 3,093 \\
\hline 980 & 985 & 879 & 1,058 & 1,721 & 1,012 \\
\hline 2,000 & 1,925 & 1,939 & 1,872 & 1,893 & 1,810 \\
\hline 96,175 & 106,310 & 104,425 & 158,734 & 141,004 & 160,987 \\
\hline 21,175 & 20,680 & 21,213 & 22,291 & 24,056 & 29,146 \\
\hline 26,195 & 32,555 & 32,061 & 46,159 & 40,239 & 45,927 \\
\hline 1,425 & 1,490 & 1,466 & 2,376 & 1,802 & 1,996 \\
\hline 5,835 & 5,995 & 6,160 & 7,260 & 5,776 & 6,417 \\
\hline 20,580 & 21,280 & 21,415 & 16,644 & 22,261 & 19,078 \\
\hline
\end{tabular}

Source: Institut de la statistique du Québec (population estimations 2006 and 2011); Authors calculation (simulations) 
Appendix 3

Relative differences in projected populations in 2031, scenario B compared to scenario A

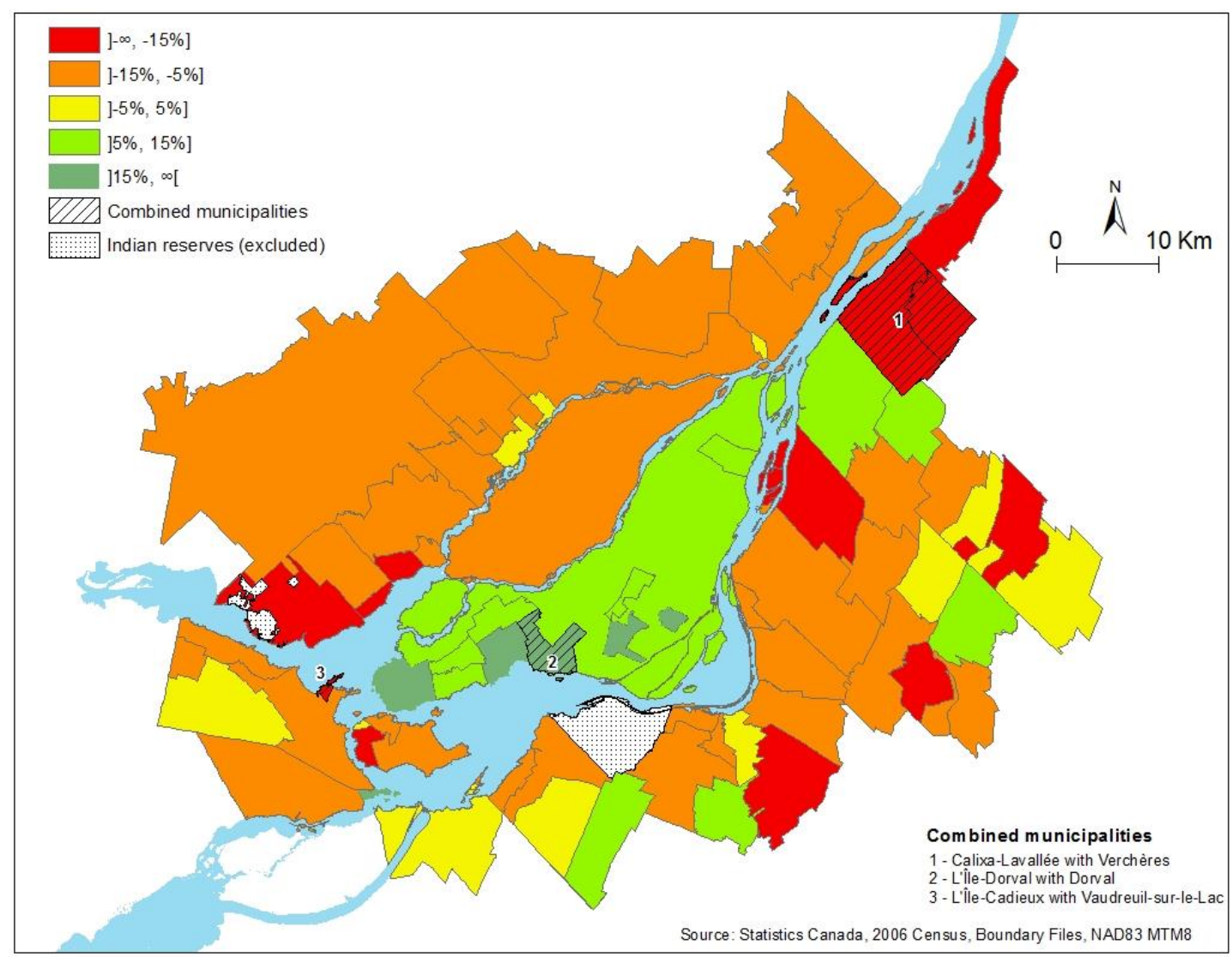


Appendix 4

Relative differences in projected populations in 2031, scenario $C$ compared to scenario A

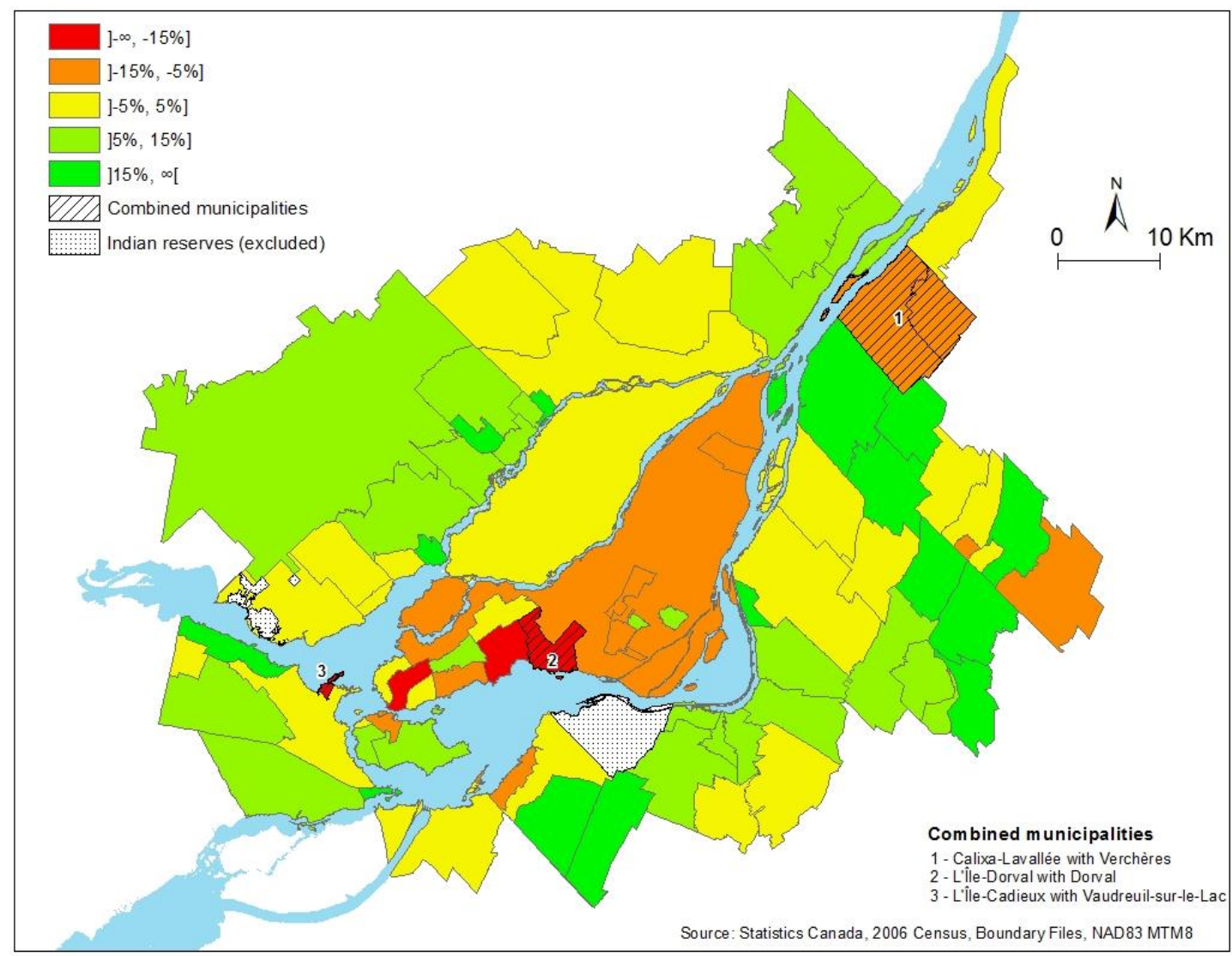

